Acta vet. scand. 1973, 14, 245-253.

From the Department of Pathology and the Laboratory of Electron Microscopy, College of Veterinary Medicine, Helsinki, Finland.

\title{
ON THE ULTRASTRUCTURE OF MAST CELLS AND GLOBULE LEUCOCYTES IN THE COMMON BILE DUCT OF CATTLE CHRONICALLY INFECTED WITH FASCIOLA HEPATICA*
}

\author{
By \\ Timo Rahko
}

\begin{abstract}
RAHKO, TIMO: On the ultrastructure of mast cells and globule leucocytes in the common bile duct of cattle chronically infected with Fasciola hepatica. Acta vet. scand. 1973, 14, 245-253. - Mast cells and globule leucocytes in the walls of the common bile ducts of seven uninfected slaughtered cows and of five cows chronically infected with Fasciola hepatica were studied by electron microscopy. The mast cells displayed numerous small intracytoplasmic granules, the matrixes of which were either strongly electron-opaque and homogeneous or less dense with a fine-granular ultrastructure. Unattached ribosomes were abundant in the cytoplasm of the cells. Many mast cells in the walls of chronically infected bile ducts were normal-looking while the cells in the subepithelial tissues often showed striking irregularities in the ultrastructure of the granules. Globule leucocytes were most numerous in the surface epithelium and were not connected by desmosomes to the epithelial cells. The nuclei of the globule leucocytes were similar to those in the mast cells except that indentations caused by the globules were more usually seen. The globules were considerably larger than the mast cell granules but bounded by similar agranular capsules. The matrix of most globules was dense and homogeneous while the other globules showed dense reticulate or lamellate structures. The relationship between the mast cell and globule leucocyte in the liver is briefly discussed with reference to recent reports on these cells in the intestinal wall.
\end{abstract}

electron microscopy; mast cell; globule leucocyte; fascioliasis; cattle.

Previous light microscopical studies have shown close similarities in the appearance and histochemistry of mast cells and globule leucocyites in the bile-duct walls of cattle chronically infected with Fasciola hepatica (Rahko 1970, 1971). These cells

* Supported by grants from the National Research Council for Medical Sciences and the Finnish Veterinary Medical Fuundaticn. 
increase in number during chronic fascioliasis in cattle, and examinations of mice experimentally infected with fascioliasis showed that the proliferation of hepatic mast cells preceded the appearance of the first globule leucocytes in the bile-duct epithelium. Further, in experimentally infected mice the subepithelial mast cell and the intraepithelial globule leucocyte in the walls of the common bile duct were ultrastructurally similar (Rahko 1971).

The purpose of the present study was to investigate the ultrastructure of mast cells and globule leucocytes in the walls of the common bile duct in cattle chronically infected with $F$. hepatica. Since bovine mast cells of the bile-duct walls have not been previously studied with electron microscopy, their normal ultrastructure is briefly described, too.

\section{MATERIAL AND METHODS}

The present material was selected from that collected for the author's previous electron microscopical study (Rahko 1973) and consisted of tissue specimens from the walls of the common bile ducts of five cows chronically infected with $F$. hepatica and of seven uninfected cows examined as controls. The material was prepared according to the methods previously described in detail (Rahko 1973) and examined with an Akashi electron microscope in the Laboratory of Electron Microscopy, College of Veterinary Medicine, Helsinki.

\section{Control animals}

\section{RESULTS}

Light microscopical examination of toluidine blue-stained thick sections cut from the Epon-embedded blocks was useful in distinguishing the $\mathrm{m}$ ast cell from the other cells with intracytoplasmic electron-opaque bodies. The granules of mast cells stained blue or purple with this method, and the cells could of ten be traced and studied in corresponding thin sections with the electron microscope.

The mast cells usually had more or less elongated outlines, and of ten displayed irregular cytoplasmic processes. No desmosomal connections were observed between them and the other cells. Their nuclei varied in form and chromatin density. Some nuclei were similar to those of the lymphocytes (Fig. 1), while 

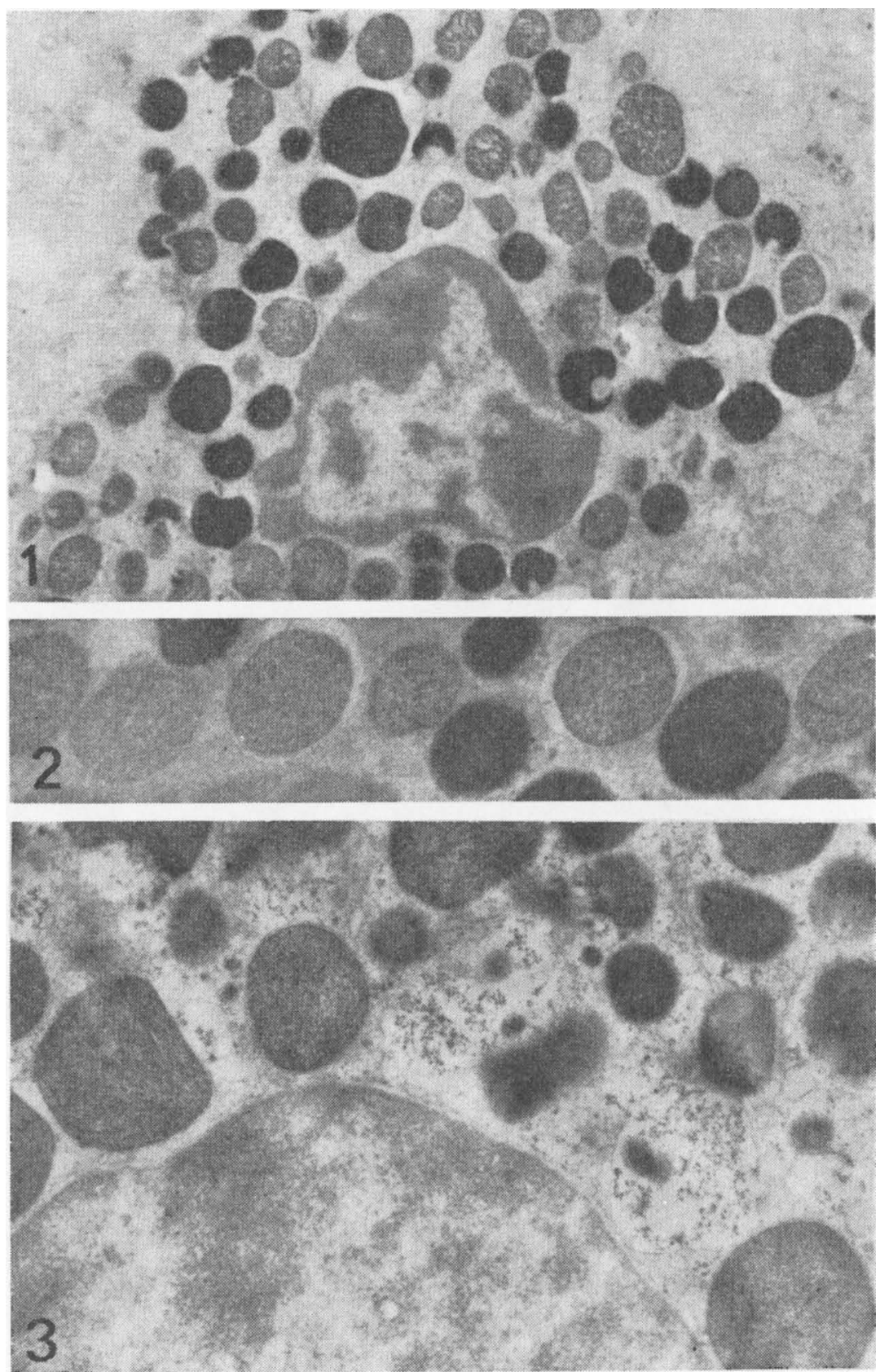

F i gures 1-3. Electron micrographs of mast cells in the wall of the common bile duct in control animals. The mast cells display granules possessing both strongly electron-opaque, homogeneous matrixes and less dense, fine-granular matrixes (Fig. 1 . $\times 8,500$ ), encircled by agranular membranes (Fig. 2. $\times 20,000$ ), and unattached ribosomes are abundant in the cytoplasm (Fig. 3. $\times 20,000$ ). 

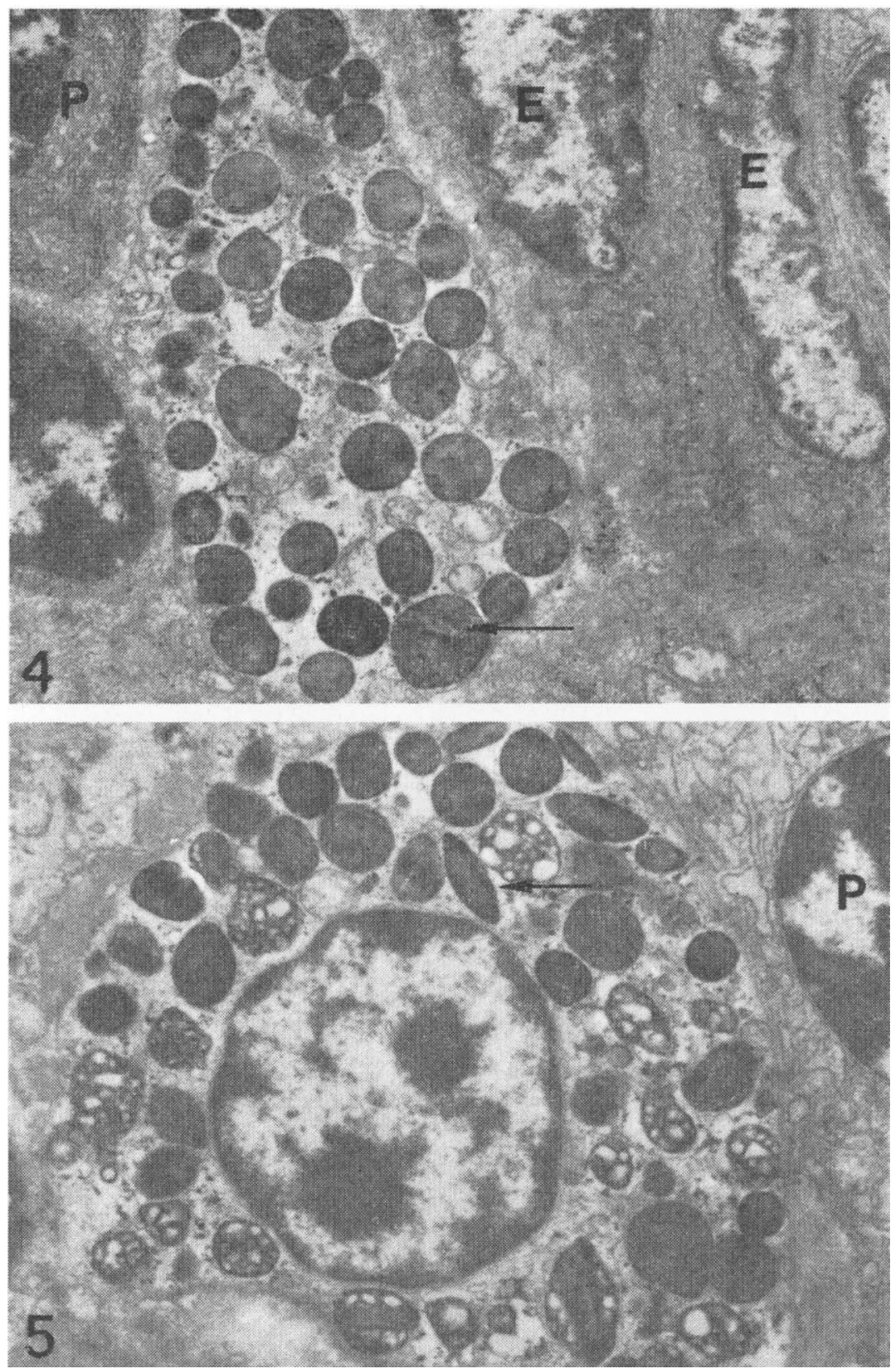

F ig u r e s 4-7. Electron micrographs of sections of the common bile ducts of cattle with chronic fascioliasis.

Figure 4. The ultrastructural appearance of this mast cell is fairly normal, except for one granule marked with an arrow. E: bileduct epithelial cells; P: plasma cell. $\times 10,000$.

Fig u r e 5. Eosinophilic granulocyte showing normal-looking (e.g. arrow) and immature-looking granules. $\times 10,000$. 

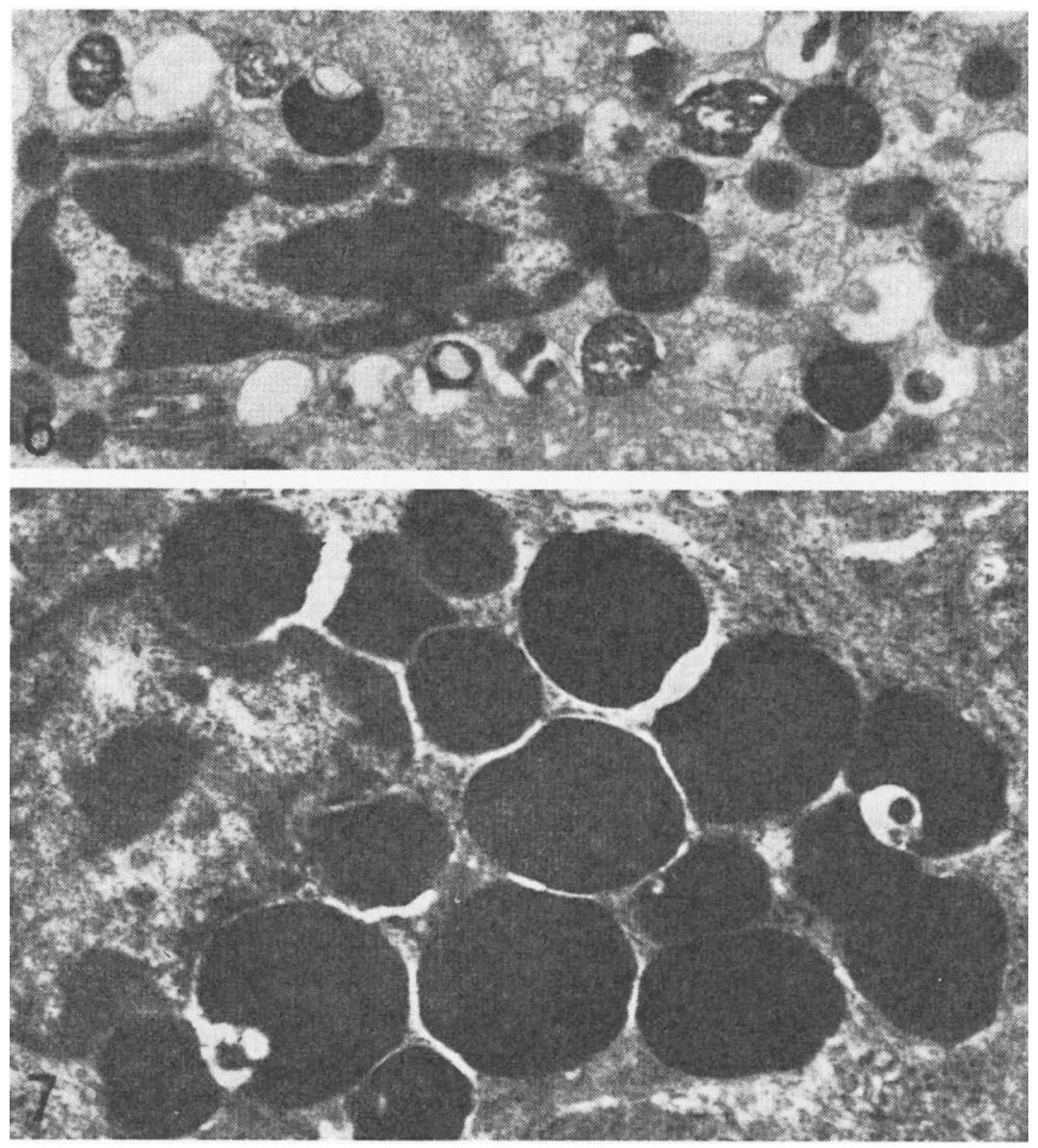

F ig u r e 6. Mast cells located in subepithelial tissues may show striking abnormalities in the ultrastructure of the granules. (Cf. Figs. $1-3) . \times 12,000$.

F ig u re 7. Globule leucocyte in the bile-duct epithelium showing indentations in the nucleus caused by large dense spherical globules. $\times 8,500$.

others showed fairly sparse chromatin and an elongated form with indentations caused by the granules.

The granules of the mast cells were bounded by a smoothsurfaced membrane, but their size and the structure of their inner matrix varied (Figs. 2 and 3 ). Some granules were moderately or strongly electron-opaque, whereas others were less dense with a fine-granular matrix. The membrane bounding the granules was usually closely apposed to them (Fig. 3), but in 
some granules a translucent halo was seen between the core and the capsule (Figs. 1 and 2). In a few granules this space contained faintly electron-opaque homogeneous or granular substances. Other cytoplasmic organelles observed in the cells were sparsely distributed in the cytoplasm except for unattached ribosomes, which were fairly abundant (Fig. 3). Only occasional globule leucocytes were encountered in the examined tissue specimens and they appeared similar in structure to those observed in the infected bile ducts.

\section{Fascioliasis}

The appearance of many $\mathrm{m}$ a s $\mathrm{t} \mathrm{c}$ ell $\mathrm{s}$ was similar to that of the cells examined in the control animals (Fig. 4). However, the structure of their granules was observed to be more irregular than normal. The eosinophilic granulocytes frequently observed in the examined tissues also possessed granules of variable structure, many of which were similar to the mast-cell granules (Fig. $5)$. The mast cells located in the subepithelial tissues showed the most striking irregularities in the appearance of the granules (Fig. 6). In addition to normal granules, these cells contained granules with fragmented matrixes and empty capsules remaining from disrupted granules.

The frequency of g lob u le le u c o c y t e s varied between the cases studied but they were always most numerous in the surface epithelium. In toluidine blue-stained sections some globules of the globule leucocytes stained strongly and some weakly, while others did not stain at all.

The globule leucocytes showed cytoplasmic processes projecting into the intercellular spaces, but were not connected by desmosomes to the epithelial cells. Their nuclei were largely similar to those in the mast cells, except that indentations caused by the globules were more usual (Fig. 7). The cytoplasm was filled with large globules, which were often two or three times as great as the mast-cell granules. The globules were encircled by agranular capsules with more or less rounded outlines except for depressions made by adjacent globules (Fig. 7). The matrixes of most globules were strongly electron-opaque and appeared homogeneous at the magnification levels employed. Occasional globules showed fragmented dense reticulate or lamellate structures instead of homogeneous matrixes. Other cytoplasmic organelles could rarely be seen in the cells, owing to the globules filling the cytoplasm. 


\section{DISCUSSION}

Previous light microscopy of the mast cells in bovine bile ducts showed that the mast cells of the connective tissues differed somewhat from those of the subepithelial tissues (Rahko 1971). The granules of the connective tissue mast cells were small and identifiable only by histochemical methods designed to reveal sulphomucins and by methyl green-pyronin staining. The mast cells in the subepithelial tissues of the bile ducts displayed somewhat larger granules visible even in haematoxylin-eosin-stained sections, though sulphomucins were shown in them, too (Rahko 1971). This electron microscopical study did not reveal corresponding differences, but the present material is too restricted to allow any definite conclusions, and the mast cells in the walls of the intrahepatic bile ducts will also be examined in further ultrastructural studies by the present author.

The ultrastructural characteristics observed in the mast cells of the bovine bile ducts were largely similar to those in the corresponding cells of the mouse (Rahko 1971). Further, the ultrastructure of bovine mast cells was not shown to differ essentially from that characteristic of the mast cell in other animals (e.g. Selye 1965, Combs 1966, Murray et al. 1968, Vollrath \& Wahlin 1970, Miller 1971 a, b).

Light and electron microscopy gave contradictory results regarding the presence of ribonucleic acid in the granules of mast cells in bovine and murine liver (Rahko 1971). In both cattle and mouse a ribonuclease-labile pyroninophilia was observed in the mast-cell granules, while this and a previous electron microscopical study (Rahko 1971) revealed that both the membrane bounding the granules and their matrix were devoid of ribosomes.

Pyroninophilia of the granules of mast cells has also been described previously, but conflicting ideas on the identity of the pyroninophilic substance are found in the literature (see Selye). Hottendorf et al. (1966) suggested that the granules of the neoplastic mast cells of the dog contain ribonucleic acid, though they also showed that heparin in vitro displayed affinity for pyronin. In cattle and mouse the cytoplasmic matrix around the granules of mast cells contained abundant free ribosomes. It is suggested that in bovine and murine mast cells true pyroninophilia may originate from the free ribosomes, but that heparin present in the granules may possibly produce a false pyroninophilic reaction also in vivo. 
Bovine globule leucocytes showed a zonal differentiation in the histochemical composition of the globules in that the cortices presented a staining reaction for sulphomucins, while carboxymucins and basic proteins were present in the cores (Rahko 1971). However, corresponding differences could not be observed in the ultrastructure of the globules. In cattle the common bile duct is not invaded by the flukes. Since globule leucocytes were not examined in the intrahepatic bile ducts in the present study, it is not certain whether globule leucocytes at the sites harbouring flukes present an ultrastructure similar to that of the cells described in this investigation.

The results obtained in light and electron microscopical studies by the present author (Rahko 1971) have indicated that there may be a close relationship between the mast cells and globule leucocytes in the liver. This impression agrees with recent reports by other investigators on the intestinal mast cell and globule leucocyte (e.g. Murray et al. 1968, 1971, Miller 1971 a, b, Miller \& Jarrett 1971). These authors have established that during parasitic infections the intestinal mast cell migrates into the epithelium, and after changes in the histochemistry of the granules produced by the secretion of the cell, assumes the appearance of a cell long known as the globule leucocyte. Miller also suggested that the mast cells proliferating in the intestinal wall during parasitic infections originate from the lymphocytes. This indicates the need for further studies on the relationship between hepatic mast cells and globule leucocytes during fascioliasis.

\section{REFERENCES}

Combs, J. W.: Maturation of rat mast cells. An electron microscope study. J. Cell Biol. 1966, 31, 563-575.

Hottendorf, G. H., S. W. Nielsen \& A. J. Kenyon: Ribonucleic acid in canine mast cell granules and the possible interrelationship of mast cells and plasma cells. Path. Vet. 1966, 3, 178-189.

Miller, $H$. R. P.: Immune reactions in mucous membranes. II. The differentiation of intestinal mast cells during helminth expulsion in the rat. Lab. Invest. 1971 a, 24, 339-347.

Miller, $H$. R. P.: Immune reactions in mucous membranes. III. The discharge of intestinal mast cells during helminth expulsion in the rat. Lab. Invest. $1971 \mathrm{~b}, 24,348-354$.

Miller, H. R. P. \& W. F. H. Jarrett: Immune reactions in mucous membranes. I. Intestinal mast cell response during helminth expulsion in the rat. Immunology 1971, 20, 277-288.

Murray, M., H. R. P. Miller \& W. F. H. Jarrett: The globule leukocyte and its derivation from the subepithelial mast cell. Lab. Invest. 1968, 19, 222_234. 
Murray, M., W. F. H. Jarrett \& F. W. Jarrett: Mast cells and macromolecular leak in intestinal immunological reactions. The influence of sex of rats infected with Nippostrongylus brasiliensis. Immunology 1971, 21, 17-31.

Rahko, T.: Globule leukocyte and mast cell in bile ducts of cattle naturally infected with liver flukes. Acta vet. scand. 1970, 11, 219-227.

Rahko, T.: Studies on the pathology of bovine and murine liver infected with Fasciola hepatica with reference to the mast cell and globule leucocyte. Ann. Acad. Sci. fenn. A 5 1971, 148, 162 (Thesis).

Rahko, T.: On the ultrastructure of epithelial cells in bile ducts of cattle chronically infected with Fasciola hepatica. Acta vet. scand. 1973, 14, 233-244.

Selye, H.: The Mast Cells. Butterworth Inc., Washington 1965.

Vollrath, L. \& T. Wahlin: Uber die Entstehung von Mastzellgranula. (The genesis of mast cell granules). Z. Zellforsch. 1970, 111, 286-292.

\section{SAMMANFATTNING}

Mastcellernas och de globulära leukocyternas ultrastruktur i gallgdngen hos nötkreatur med kronisk infektion av Fasciola hepatica.

Mastceller och globulära leukocyter i gallgångsväggen hos sju oinfekterade slaktkor och hos fem med kronisk infektion av Fasciola hepatica studerades elektronmikroskopiskt. Mastcellerna uppvisade ett stort antal små intracytoplasmatiska granula. Dessa granulas matrix var antigen mycket elektrontätt och homogent eller mindre elektrontätt, uppvisande en fingranulär ultrastruktur. Fria ribosomer förekom mycket rikligt i cytoplasman. I väggarna av kroniskt infekterade gallgångar var flera mastceller morfologiskt normala medan cellerna i den subepiteliala vävnaden ofta uppvisade höggradiga oregelbundheter i granulas ultrastruktur. Globulära leukocyter förekom mest i ytepitelet och var inte sammanbundna med epitelcellerna genom desmosomer. De globulära leukocyternas kärnor liknade mastcellernas kärnor med den skillnaden att globulära indentationer oftare förekom hos de först nämnda cellerna. Till storleken var globuli betydligt större än mastcellgranuli men omgivna av liknande agranulära membran. För det mesta var det globulära matrixet tätt och homogent, en del globuli uppvisade en tät reticulär eller lamellär struktur. Sambandet mellan mastceller och globulära leukocyter i levern diskuteras i korthet med beaktande av tidigare uppgifter om dessa celler i tarmväggen.

(Received January 25, 1972).

Reprints may be requested from: Timo Rahko, Department of Pathology, College of Veterinary Medicine, Hämeentie 57, 00550 Helsinki 55, Finland. 